\title{
FACEBOOK USAGE TOWARDS READING INTEREST AT NEWS PORTAL MERDEKA.COM IN NORTH CIKARANG
}

\author{
Juvenia dan Dindin Dimyati \\ President University, Jababeka Education Park, Cikarang Utara, Indonesia, \\ No Hp. +6281973159153, \\ Email: juvenia1195@gmail.com,dindin.dimyati@president.ac.id
}

\begin{abstract}
Popularity of social media have grown since the early of 2000. They have eased people in exchanging information and sustaining relationship. In addition, social media have become an alternative for news distribution and consumption. One of popular social media platforms is Facebook in which many media organizations have utilized it as a medium for sharing information including news to provide up-to-date information, to increase article views, as well as to increase website traffics to visit their news portals. This research attempted to investigate the influence of Facebook usage towards reading interest at news portal merdeka.com, a study in North Cikarang. Theory used in this study wasUses and Gratification and the method was quantitative in nature. The data were collected through questionnaires for 100 respondents and SPSS 20 was employed to process the data. The result has shown that Facebook usage influenced 30.6\% towards reading interest at news portal merdeka.com and the regression coefficient values obtained in this study was $Y=5.489+0.575 X$. In short, Facebook as a publication medium used by merdeka.com has successfullyincreasedreading interest to its news portal.
\end{abstract}

Keywords: social media, Facebook, news portal, reading interest.

\begin{abstract}
Abstrak
Popularitas media sosial telah berkembang sejak awal tahun 2000. Mereka telah mempermudah orang dalam bertukar informasi dan mempertahankan hubungan. Selain itu, media sosial telah menjadi alternatif penyebaran dan konsumsi berita. Salah satu platform media sosial yang populer adalah Facebook dimana banyak organisasi media memanfaatkannya sebagai media untuk berbagi informasi termasuk berita untuk memberikan informasi terkini, untuk meningkatkan tampilan artikel, dan juga untuk meningkatkan trafik situs web untuk mengunjungi portal berita mereka. Penelitian ini bertujuan untuk mengungkap pengaruh penggunaan Facebook terhadap minat membaca di portal berita merdeka.com, sebuah studi di Cikarang Utara. Teori yang digunakan dalam penelitian ini adalah Kegunaan dan Gratifikasi dan metodenya bersifat kuantitatif. Data dikumpulkan melalui kuesioner untuk 100 responden dan SPSS 20 digunakan untuk mengolah data. Hasilnya menunjukkan bahwa penggunaan Facebook mempengaruhi 30,6\% terhadap minat baca pada portal berita merdeka.com dan nilai koefisien regresi yang diperoleh dalam penelitian ini adalah $Y=5,489+0,575 X$. Singkatnya, Facebook sebagai media publikasi yang digunakan oleh merdeka.com telah berhasil meningkatkan minat baca ke portal berita.
\end{abstract}

Kata kunci: sosial media, Facebook, portal berita, minat baca

\section{Introduction}

The rise of the Internet has provided lot of influences and changes in human life. If once the communication between humans was limited by space and time, hence the presence of internet has eroded those boundaries and provide more consumer choices in communication (Waldman, 2011). Based on Internet World Stats (2016),Indonesia ranked
5 out of 20 countries with highest number of internet users which reached up to 132 million active users. As a result of Internet use, users are now able to get the information of current situation in region or country rapidly through online and able to choose the most relevant, valuable, entertaining, or insightful information without having to rely on conventional media, such as reading 
it on newspaper, listening to new bulletin on radio, or watching it on television (Boyd, 2008). It is supported by the research from UC Browserwhich showed that 95.4 percent of Indonesian are likely to rely on the Internet as top choice for information (2016, as cited in Wardani, 2016).

Social media, as a result of internet development have grown since the early of 2000 and are currently popular among societies. They have eased people in exchanging information, making friends, and sustaining relationship. Besides, the rapid business world today has made competition among business become more intense and serious in which social media have been used as marketing tool by many business across different industries to create interaction with publics, promote as well as to enlarge their business(Infinitdatum, 2015; Pereira et al., 2014; Kaplan \& Haenlein, 2010).

In this context, media organizations or mainstream media have utilized social media as a publication medium with the aim to meet the information needs of societies, provide up-to-date and quick information (Franklin, 2008). According to Picard (2009) and Yan et al. (2011), social media have currently been used as alternatives sources for news distribution and consumption to provide hyperlink/linkage of their news. Palser, B. (2011) studied that by publishing through social media, they enable media organizations to engage with audiences, create interactive and quick communication, to increase website westtraffic, article views, as well as their economic success.
The most famous social media platform worldwide with more than 1 billion active users and ranked third as the top site globally after Google and YouTube is Facebook (Alexa, 2016; Facebook Newsroom, 2016). In Indonesia, Facebook is the top active social media platform with 77.58 million users and is in the fourth place after India, United States, and Brazil (We Are Social, 2016).Facebook is an easyto-use application with free registration that available in 37 different languages and includes several public features for communication, such as: Profile - where users can express who they are and post what is going on; News Feed - updating list of stories and the sharing activity from Facebook connections; Groups - a private space to share common interest with small groups of people, like family, teammates, or best friends; Events - allows users to organize an event, invite guests, and send notifications and reminders to their friends; Pages - public profiles for artists, public figures, business, brands, and organizations to create a presence and connect with their community; Messenger - a messaging application that allows users to send private messages to other Facebook users; Photos - allow users to upload photos; Videos allow users to share and watch videos; and Search - allow users to find any posts and people.

One of the online news portal that utilizes Facebook as its main publication medium is merdeka.com. According to Alexa, international rating site (2016), merdeka.com places the fifth rank as the 
top most popular news portal in Indonesia after Tribunnews.com, detik.com, liputan6. com and kompas.com. Besides, according to its research, merdeka.com becomes more well-known because of its publication on Facebook since Facebook is one of the site that drives traffic to merdeka.com website. merdeka.com differs from most other news portals, where most of them are built as part of the development of traditional printed or broadcast media companies while merdeka. com is purely part of digital media company which once built by technology company that consisted of people who know web server earlier than journalism (merdeka. com). Moreover, merdeka.comdoes not have other forms of media (printed or broadcast). News portal merdeka.com is a media organization which provides upto-date information on the rubrics at its website page. However, due to the existence and emergence of many other news portals in Indonesia lead to competition among them, making merdeka.com has to compete and finds ways to attract readers as many as possible. In addition, since it is not ranked as the top most popular news portal, it might not become the preferred news portal to obtain information. Therefore, one of the efforts of merdeka.com is through frequently publishing any up-to-date information from any rubrics to Facebook to increase the reading interest towards its news portal.

Against this background, this study aims to answer the following research questions: RQ1: How does the usage of Facebook as publication medium?

RQ2: How is the respondent's reading interest at news portal merdeka.com on Facebook?

RQ3: How much does Facebook influence reading interest at news portal merdeka.com?

Researcher hypothesis on this research is:

Ha: Facebook usage has significant influence towards reading interest at news portal merdeka.com

This research would give important significances to related parties both for academic and practical. To academic significance, it aims to enhance knowledge and provide insight about communication, especially on the usage of Facebook as publication medium, as well as can be used as a basis and reference for future researcher in conducting similar research. For practical significance, it would be important for company, public relations practitioners and to society. For company, the result of this study can be used by merdeka.com to identify and evaluate the publication on Facebook. Therefore, merdeka.com can take action whether to have better publication on Facebook or on other media. For Public relations practitioners, it can provide understanding about the effectiveness of publicity through social media. For society, it is expected to provide knowledge about the use of social media Facebook as publication medium.

The development of technology Web 2.0, an online technology or website that allows users to interact and collaborate among internet users, has brought wide range of media options for public to consume, produce as well as distribute news across the whole network (Stassen, 2010; Tech Target, 2015). Ludtke (2009) emphasizes on 
social media, the new media that transform the way people receive and share news. New media are defined as a general term for a network or the Internet, mobile phones, or a different set of communication technology that have certain up-to-date features. New media are digitally made for individuals as communication tool to provide an open, flexible, interactive, dynamic information environment that allows individuals around the world to have mutual sharing, feedback and creative participation (Hearn et al, 2009).

Pierre Levy as the pioneer of new media theory,(as cited in Dijk, P. J., 2005) in The Network Society: Social Aspects of New Media, explains two dominant views of the differences between the first media age (broadcast) and the second media age (networks), which are about the social interaction approach and social integration approach. The social interaction approach differentiates media in term of how close the model of face-to-face interaction, where older form of media reduced the possibility of interaction, while the new media are more interactive and create a new sense of personalized communication. The integration approach differentiates media in term of how people use media as way to create community. Old media centralized on the source of information which audiences recognized, while the use of new media are as a shared ritual that makes individuals feel part of something bigger (as cited in Veltman, 2006).

Kaplan \& Haenlein (2010) defines social media as group of internet-based application as the result of Web 2.0 that allow for the creation and exchange of user-generated content. It is considered as an important platform of virtual communications where enable millions of users to create a personal profile, identify and connect with other users and organizations to share information, knowledge and maintain social ties (Boyd \& Ellision, 2008).It also enables any organizations to connect with their public with lower cost and higher efficiency than other traditional communication tools (Hassan, et al. 2015).Based on Hermida, et al. (2012), there are three categories of social media users which are high users refer to those who visited social media several times a day or at least once a day, medium users refer to those who visited at least once a week or once a month, and low users refer to those who visited less than once a month or not at all.

Gentle (2012) and Agichtein et al., (2008) (as cited in Hosan, A., 2015) explain the differences of social media and traditional media, where social media is operating in a dialogic transmission system or known as from many sources to many receivers, while traditional media is operating in monologic transmission model where the source is from one to many receivers. Besides, social media have several characteristics that differentiate from traditional media, which are in terms of reach, accessibility, usability, immediacy, and permanence. In term of reach, social media are capable to reach a global audience and reach wide range of information worldwide. Accessibility means that widespread communication is open for all, where it eases users to obtain information with an affordable cost and time 
efficiency, without have to own a printing press or broadcast outlet to deliver message. Usability means that social media is easy and quick to use as it does not require any special skills or training, where anyone can operate the use of social media. Immediacy means that social media is bringing virtually instantaneous response and interaction for public consumption, and permanence means that content published on social media can be altered almost instantaneously by editing in order to provide up-to-date information.

In this context, social media platform, Facebook, which launched in February 2004 , was originally a platform for personal space to share information about oneself, but then has been used as a platform for sharing external content to social network (Oeldorf, A., \& Sundar, S., 2015). With more than 1 billion users worldwide, Facebook has been used for people to stay connected with their family and friends, to discover the current situation happening in the world, as well as to share and express what matters to them (Facebook Newsroom, 2016). Because of its popularity, there are many researchers did a study about Facebook. For instance, recent studies are about the usage of Facebook for business-to-consumers (B2C) communication (Kwok, L., \& Yu, B., 2015), Facebook as an alternative new source among university students (Mesole, F., 2014), and for news consumption (Howe, J., 2011).

According to Leonard (2012, as cited in Kwok, L.,2015) since 2008 where organizations were allowed to build Facebook page for business purpose,
Facebook has become the most popular and important platform used by organizations because it represents an opportunity to enhance interaction with their current and potential customers through profiles, groups and pages, where "Like" and "Share" on Facebook are becoming important for any business organizations (Li \& Bernoff, 2008). However, Kwok, L., \& Yu, B. (2015) suggested that Facebook is not effective for business organizations to share messages regarding to sales and promotion of company's brand, product or service, but is more effective for communication tool to send conventional messages. Chandon (1995) (as cited in Ricardo, 2016), agreed that social media Facebook is more efficiently used for providing pleasure or emotional benefits to users, rather than commercial benefits. Therefore, researcher concludes that news media organizations still have a big opportunity to utilize Facebook and attract Facebook users, since the main aim of news media organizations are not for promoting product or brand but to provide the information needs of users. Purcell et al. (2010) supported researcher statement, where he claimed that majority of news consumers get news updated on their Facebook page, either users directly get it because of following the page of news media or because of their social networks who share the news. News media organizations are creating Facebook page for publishing short news or links of articles which can be liked, commented, or shared as well as to direct users to visit their news portal (Winter, Brückner, \&Krämer, 2015). 
Based on Haristya \& Suwana (2012), online news media in Indonesia is divided into two categories based on the initial set up as media publishers, which are first; online news portalas part of development form their presence in traditional printed media or broadcast, for instance JawaPos, Kompas, Liputan 6, second is those online news portal which do not have another form of media, for instance merdeka.com, detik. com, okezone.com, although some might belong to the group of media, for example okezone.com is part of MNC group, and detik.com is part of Trans Corporation. News portal is defined as a website or web page that contains the various types of news, with several characteristics in terms of content, functionality, navigation, audio visual quality, and interactivity. In terms of the content, news portal still uses the inverted pyramid technique as the rules of news writing, however, the writing style of news portal is less formal and should not be more than five lines of words each paragraph. In terms of functionality, many news portals connect their articles to social media, in order to ease the readers in obtaining news. In term of navigation, news portal offers several rubrics to facilitate their readers whom wish to read further on their specific topic of choice or interest. In term of audio visual quality, many news portals have added video to support the news, and in term of interactivity, news portals provide a space for readers to provide feedback and enable readers to share the news to their social media site (Niles, R., 2015 as cited in Currie, T., 2006).
According to Paul Bradshaw (as cited in Eki, 2016) there are five basic principles of online journalism shortened as B-A-S-I-C (Brevity, Adaptability, Scannability, Interactivity, Community and conversation). The first principle is brevity which explains that in the writing of online journalism should be short, concise, and clear. Second is adaptability which explains that journalists must be able to adapt to the technology. Journalists are required to be able to use some applications from the internet, for example hypertext, audio, video, animation, live chat, etc. An online journalism should also be able to meet the criteria of skill such as actual writing skill and depth of information writing skill. Third is scannability which explains that news published on news portal should be easy to understand and allow users to find desired specific information. Next is interactivity which explains that in online journalism allows interaction and interactivity in three directions, between journalists and user, user and journalist, and user with another user through the column of comment. Last is community and conversation which explains that good journalism is those capable to establish mutual relationship with users, which allow users to actively involve as contributor or editor.

Hopkins (2010) studiesthat Facebook has become the most visited site as news source among all social media sites available as it is one of the leading platform that frequently refers to news portal through links shared by friends of their networks. Another research conducted by Statista, 
2016 (as cited in Zuhra, 2016), showed that Facebook contributed more on the numbers of visits to news portal rather than the search engine Google, where Facebook contributed 41.4 percent while Google only contributed 39.5 percent. News media organization which are operating in a very competitive markets to reach audiences and advertising revenues are eyeing the potential of Facebook as social media for news consumption, most news organizations established their own Facebook page and hired social media specialist to share hyperlinks in order to drive traffic to visit their news portal (Hille\& Bakker, 2013).

Sharing information from news Pages on Facebook is an easy way by only clicking "Share", and it will appear on the Facebook wall that can be views by the Facebook friends, in which can direct others attention to the news and increase the Page's exposure (Hermida, 2009).Hermida, A. et al (2012) and Singer et al. (2011), explained that news media organizations all around the world have been viewing and using Facebook because of its high number of users as their strategy for market growth plan to reach as many audiences and encourage more users to like and share their content.

Further, Howe, J. (2011) claimed that Facebook provides wider opportunity to news media organizations to engage younger audiences from 18-34, where nearly half the people who are news consumer and tend to like as well as share articles on news website are from 18 to 34 years old. It is supported by the research from Statista, 2016 (as cited in Zuhra, 2016) which showed that $64 \%$ of online news consumption is users from all ages ranging from 18 to $50+$ with majority $64 \%$ of users with age 18 to 24 . Another study by Baresch et al. (2011), reveals that about $49 \%$ of Facebook users share news information through links. Therefore, by publishing articles on the most popular social media site, it allows news media organization to reach as many readers because when a user likes or shares the links updated by news media organization, it will be posted on the user's Facebook wall, which help to spread the news. In addition, on average, Facebook users have at least more than 300 Facebook friends which directly give more exposure to the article they shared.

Theory Uses and Gratificationinitiated by Blumer and Katz (1974, as cited in West $\&$ Turner, 2010)emphasizes on the users and their active role in choosing and using media that can satisfy one or more of their needs. Uses and gratification theory also explains that users are self-aware and are able to understand the reasons why they use media. This theory has beenwidely used in many disciplines of study to not only for explaining the reasons why users use traditional media but also in the application of new media or social media as the theory is still relevant to the new media application because of its origin in communication literature (Whiting \& Williams, 2013). Whiting \& Williams (2013) also explained that theory Uses and Gratification helps in explaining the reasons why users use and like certain social media for fulfilling their needs. Lariscy et al. (2011) argued that theory Uses and Gratification can be relevant in helping to explain the social media uses. 
Shanahan and Morgan's (1999, as cited in West \& Turner, 2010) also suggested that although the technology changes, there is still underlying consistency of the content of the messages consumed by users.

Based on Papacharissi,Z., \&Mendelson, A. (2011), there are five categories behind the media use, which are for cognitive need means for obtaining information and knowledge to find out what is happening around, as well as to satisfy curiosity and general interest; for affective need means to satisfy the emotional needs include pleasure and other individual's emotional mood; for personal integrative means to enhance individual self-esteem as to gain personal identity, credibility and stability; for social integrative need is to enhance connections and interact with family or friends; and last for tension free need is means for escaping from tension and problems.

Further, there are five basic assumptions of the Uses and Gratification approach (Blumer and Katz, 1974, as cited in West \& Turner, 2010). First, "the audience is active and its media use is goal oriented", which explains that users are considered as active participants, who are more selective to decide specific medium to satisfy their social or psychological needs or desire. Second, "the initiative in linking need gratification to a specific medium choice rests with the audience member", means that user takes the initiative to select media that can satisfy the needs and is more powerful than media. Third, "the media compete with other sources for need satisfaction", means that each individuals have different and several needs, which in result, they select, pay attention and have media alternatives to meet the needs. Fourth "people have enough self-awareness of their media uses, interests, and motives to be able to provide researchers with an accurate picture of that use", claims that individual is aware of their media choice and their media choice is to shape their identity. Last, "value judgments of media content can only be assessed by the audience", explains that audiences are those who define the value of media content.

In this context, Facebook as new media is used by users because of various motives. Many studies analyzed the motives of using Facebook by theory Uses and Gratification. One of them is the use of social media Facebook for news consumption for their cognitive need (Mesole, F. 2014). Papacharissi, et al. (2011), found that the main factor of Facebook usage is for information sharing followed by relaxing entertainment, follow new trend, companionship, escape, and social interaction. Another research conducted by Park, Kee\&Valenzuela (2009), found out that the use of Facebook is for information seeking, socializing, and for entertainment. Moreover, Joinson, A. N. (2008) also founded that Facebook usage are for interacting with people, express their identity, and for news purpose in order to stay updated of daily news. Based on many previous studies that related with theory Uses and Gratification, it can be seen that one of the purpose in using Facebook is for information seeking as it is supported by Pew Research Center study (2016) which revealed that Facebook usage for news is significantly increasing from 47 percent in 2013 to 66 percent in 2016.Therefore, this research is related withUses and Gratificationtheory 
since users have the power to decide and filter whether the news shared by news portal merdeka.com is accordance with their needs or not

$\operatorname{Cox}(2016)$ reveals that today news consumers want the easiness to obtain information as they want the information they need to come to them. They rarely browse on news portals to look for updates but many turn to social media sites to scan headlines from a variety of news sources all at once. Howe(2011) explained that users are generally motivated to utilize Facebook to get the updated news and share on their Facebook page because they wanted to stay connected with their social network, and are enjoyed to discuss current and trending topic. Majority of respondents in her study claimed that they rely on their connections to keep informed as a result of links shared by their social networks on Facebook. However, another study by Ju\& Chyi (2014), argued that Facebook users are not that interested in news compared to Twitter users, since Facebook has various of features for users to choose on, for instance for playing games, viewing or uploading photos and videos. They claimed that Facebook is more on social network while Twitter is more on new-content social media, which according to them Twitter drives more traffic to news portal compared to Facebook. It is also being supported by Pew Study (as cited in Athena Information Solutions, 2016) which revealed that Facebook users do not have specific news site to search or follow as they are mostly unintentionally come across an article and share it.

As social media have been used as mar- keting tool bymany organizations, it is essential to considerand apply AIDA marketing model to evaluate their marketing activities. AIDA marketing model has been widely used in marketing strategies in business to emphasize on transaction and purchases by individuals; however, it can also be applied for the recognition of the existence of product or service. This model of marketing has generally known among marketing scholars and practitioners as well as has been widely applied in marketing activities either traditional or online. The application of AIDA model in digital world marketing communication is to emphasizeon how creating the existence of product or service, building relationship, and creating mutual value with publics (Hassan, et al. 2015).

In this context, news portal merdeka. com has utilized many social media, including Facebook to share information to attract readers to visit as well as read its news portal. Therefore, this research applied AIDA marketing model to analyze the successful of its marketing activity on Facebook in increasing reading interest. AIDA model (Boone \& Kurtz, 2013) stands for attention, interest, desire and action. First, it is suggested that any publication or promotional message must be able to gain the attention of audiences. If this step is not successful, then the next stage will become useless. The second stage is interest, after getting the attention of audiences; publication should be able to make audiences interested in finding out more about the publication. Third stage is desire, where publication should arouse desire, which convert the audience's interest into a 
strong desire or strong motivation to do the action, and last is action, where audiences are finally making a final decision to know more about the publication or finally elicit an action.

\section{Research Method}

The paradigm in this research was positivism in which the knowledge is collected through the verification of the experiences that can be observed by relying on testing and experiment (Nightingale, W., 2012). In order tosupport positivism paradigm, the method used in this studywas quantitative - a strong characteristic of capability to measure variables and to test hypothesis. Quantitative research is also considered to be more scientific approaching in doing social science (Bryman, A., \& Cramer, D. 2005; Creswell, J., 2013). This research used quantitative method to generalize a finding and to look at relationships between Facebook usage and reading interest at news portal merdeka.com.

The scope and limitation of this research was a study measuring the influences of social media Facebook usage towards reading interest at news portal merdeka.com on societies living in North Cikarang area. North Cikarang is a developing city proved by the existence of industrial area Jababeka. The societies are heterogeneous in describing the phenomena as

Table 1.Operational Concept of Variable X

\begin{tabular}{|c|c|c|c|}
\hline Variable & Indicator & Descriptor & Scale \\
\hline \multirow[t]{5}{*}{$\begin{array}{l}\text { Social Media Face- } \\
\text { book (Variable X) } \\
\text { (Gentle, } 2012 \text { and } \\
\text { Agichtein et al., 2008) }\end{array}$} & Reach & $\begin{array}{l}\text { - Reach of information on Facebook } \\
\text { - Reach of people globally }\end{array}$ & Ordinal \\
\hline & Accessibility & $\begin{array}{l}\text {-Easiness to obtain information on Facebook } \\
\text {-Effectiveness of information obtained through Facebook } \\
\text {-Affordable cost in obtaining information on Facebook }\end{array}$ & Ordinal \\
\hline & Usability & $\begin{array}{l}\text {-Speed and accuracy in obtaining information } \\
\text {-Easy to use without any special skill }\end{array}$ & Ordinal \\
\hline & Immediacy & - Quick response and interaction & Ordinal \\
\hline & Permanence & $\begin{array}{l}\text {-Instantaneously alter content by editing } \\
\text {-Provide up-to-date information }\end{array}$ & Ordinal \\
\hline
\end{tabular}

Table 2. Operational Concept of Variable Y

\begin{tabular}{|c|c|c|c|}
\hline Variable & Indicator & Descriptor & Scale \\
\hline \multirow[t]{4}{*}{$\begin{array}{l}\text { Reading Interest at } \\
\text { news portal merdeka. } \\
\text { com (Variable Y) } \\
\text { (Boone \& Kurtz, } \\
\text { 2013) }\end{array}$} & Attention & $\begin{array}{l}\text { - Attention towards news caption shared by merdeka.com } \\
\text { on Facebook } \\
\text { - Attention towards picture shared by merdeka.com on } \\
\text { Facebook }\end{array}$ & Ordinal \\
\hline & Interest & $\begin{array}{l}\text { - Interesting information } \\
\text { - In accordance with readers' curiosity }\end{array}$ & Ordinal \\
\hline & Desire & $\begin{array}{l}\text { - Desire to visit website of news portal merdeka.com } \\
\text { - Desire to read rubric-rubric on news portal merdeka.com }\end{array}$ & Ordinal \\
\hline & Action & $\begin{array}{l}\text { - Read the news on merdeka.com } \\
\text { - Involvement of others to publish the news }\end{array}$ & Ordinal \\
\hline
\end{tabular}


they represent any ages and background.

The population of North Cikarang societies based on Badan Pusat Statistik Kabupaten Bekasi (2014) was 98.852, with 100 as the sample size obtained through Slovin Formula with $10 \%$ margin of error. The sampling technique on this research wassimple random sampling - a probability sampling. Researcher collected data by using questionnaire to those who have characteristics such as having Facebook account, currently living in North Cikarang, and have seen the posting of merdeka.com on Facebook.

The two variables in this research wereFacebook usage as independent variable (variable $\mathrm{X}$ ) and reading interest at news portal merdeka.com as dependent variable (variable Y) were measured by the following indicators:

The research instrument used in this research wasclosed-ended questionnaire in which the questions were guided by the indicators of variables by choosing one alternative answer provided. The questionnaire was examined by using Likert-type scale. Respondents rated items on a five-point strongly disagree to strongly agree scale, with neutral as the midpoint.

The data analysis procedures in this research consisted of pilot test, validity and reliability, normality test, descriptive analysis, coefficient of determination and regression test. Pilot test is a small scale research project used to test the instruments on the questionnaire similar to those that will be used in the full study (Zikmund, Babin, Carr \& Griffin, 2013). According to Grover and Vriens (2006), the sample of pretest in a research is about 15 to 30 respondents. Thus, this research took the highest number from that range is 30 respondents. Validity test is to measure the instrument (questionnaire) in order to show the level of trustworthiness. A questionnaire is valid if $r_{\text {result }}>r_{\text {table. }}$ Reliability test is to measure the consistency and shows how much the instrument could be trusted. According to Zikmund et al., 0.6 Cronbach Alpha indicates poor reliability, 0.6-0.7 indicates fair reliability, 0.7-0.8 indicates good reliability, and 0.8-0.95 indicates very good reliability.

Normality test is used to ensure that the distribution of a data follow or approach the normal distribution, which in forms of bell shaped, where it is not skewed to the left or right because if the data does not follow a normal distribution pattern, it will obtain a biased estimation (Croucher \& Cronn, 2014). The method used to test the normality in this research was by using KolmogorovSmirnov test (sample is more than 50), which if the value of significant from the result is $>0.05$ (alpha), thus the data is normally distributed.Descriptive analysis is an analysis that describes the main characteristic of the data in quantitative, such as frequency, percentage and mean (Santoso, 2014).

Coefficient of determination is a measurement obtained by squaring the correlation coefficient which is the proportion of the total variance of a variable accounted for by another value of another variable (Zikmund et al., 2013). Regression analysis is a technique to measure the linear association between a dependent and an independent variable (Zikmund, Babin, Carr, \& Griffin, 
2013). It is to predict the value of dependent variable if the value of independent variable is changed. According to Zikmund et al. (2013), the formulation of regression is $\mathrm{Y}=\mathrm{a}+\mathrm{bX}$; where $\mathrm{Y}$ is dependent variable, $\mathrm{a}$ is constants or $\mathrm{Y}$ if $\mathrm{X}=0, \mathrm{~b}$ is regression coefficient, and $\mathrm{X}$ is independent variable.

\section{Result and Discussion}

Before working on full research, this research has passed the pilot test for 30 respondents. The table of corrected item total correlation of ten statements on variable $\mathrm{x}$ (Facebook usage) and the corrected item total correlation of eight statements on variable $y$ (Reading interest) were valid as $r_{\text {count }} \geq$ $\mathrm{r}_{\text {table }}(0.361)$. Meanwhile, the value ofCronbach Alpha on variable $\mathrm{x}$ was 0.900 and on variable $y$ was 0.921 , which showed that the items on variable $\mathrm{x}$ and $\mathrm{y}$ of the pilot test were in a very good reliability, hence, the instruments could be used in the main research.

From 177 respondents who participated in filling the questionnaire of main research, there were 100 respondents eligible as the samples as they were currently living in North Cikarang, have Facebook account and have seen merdeka.com posting on Facebook. The respondents were 42 males and 58 females. $76 \%$ of respondents were $18-25$ years old, $13 \%$ were 26-33 years old, 9\% were 34-41 years old, 1\% was $42-50$ years old, and $1 \%$ aged over 51 years old. There were 57 respondents with Senior High School as their latest education, 33 respondents with Bachelor, 9 with Diploma, and 1 with Doctorate. Based on their occupation, 65 respondents were students, 20 were private employee, 7 were entrepreneur, 6 were government officer, and 2 were professional (doctor, teacher, etc.), and based on their frequency in accessing Facebook, 33 respondents accessed Facebook several times a day, 20 accessed at least once a day, 14 accessed several times a week, 7 accessed at least once a week, 13 accessed several times a month, 4 accessed at least once a month,

Table 3. Respondents' Characteristics

\begin{tabular}{|c|c|c|c|c|c|c|c|c|c|}
\hline Gender & $\begin{array}{l}\text { Percen- } \\
\text { tage }\end{array}$ & Age & $\begin{array}{l}\text { Percent- } \\
\text { age }\end{array}$ & $\begin{array}{l}\text { Education } \\
\text { Level }\end{array}$ & $\begin{array}{l}\text { Percent- } \\
\text { age }\end{array}$ & Occupation & $\begin{array}{l}\text { Percen- } \\
\text { tage }\end{array}$ & $\begin{array}{c}\text { How often do } \\
\text { you access } \\
\text { Facebook }\end{array}$ & $\begin{array}{l}\text { Per- } \\
\text { centage }\end{array}$ \\
\hline Male & $42 \%$ & $18-25$ & $76 \%$ & $\begin{array}{l}\text { Senior } \\
\text { High } \\
\text { School }\end{array}$ & $57 \%$ & Student & $65,0 \%$ & $\begin{array}{c}\text { Several times } \\
\text { a day }\end{array}$ & $33,0 \%$ \\
\hline \multirow[t]{6}{*}{ Female } & $58 \%$ & $26-33$ & $13 \%$ & Diploma & $9 \%$ & $\begin{array}{l}\text { Government } \\
\text { Officer }\end{array}$ & $6,0 \%$ & $\begin{array}{c}\text { At least once } \\
\text { a day }\end{array}$ & $20,0 \%$ \\
\hline & & $34-41$ & $9 \%$ & Bachelor & $33 \%$ & Professional & $2,0 \%$ & $\begin{array}{l}\text { Several times a } \\
\text { week }\end{array}$ & $14,0 \%$ \\
\hline & & $42-50$ & $1 \%$ & Doctorate & $1 \%$ & $\begin{array}{l}\text { Private Em- } \\
\text { ployees }\end{array}$ & $20,0 \%$ & $\begin{array}{l}\text { At least once a } \\
\text { week }\end{array}$ & $7,0 \%$ \\
\hline & & $>51$ & $1 \%$ & & & Entrepreneur & $7,0 \%$ & $\begin{array}{l}\text { Several times a } \\
\text { month }\end{array}$ & $13,0 \%$ \\
\hline & & & & & & & & $\begin{array}{l}\text { At least once a } \\
\text { month }\end{array}$ & $4,0 \%$ \\
\hline & & & & & & & & $\begin{array}{l}\text { Less than once a } \\
\text { month }\end{array}$ & $9,0 \%$ \\
\hline Total & $100 \%$ & & $100 \%$ & & $100 \%$ & & $100 \%$ & & $100 \%$ \\
\hline
\end{tabular}


Table 4. Questionnaire Score on Facebook Usage

\begin{tabular}{|c|c|c|c|c|c|c|c|}
\hline No & Statement & SDA & SD & $\mathrm{N}$ & A & SA & Mean \\
\hline \multirow{2}{*}{1} & I get widespread information around the world via & 3 & 5 & 28 & 44 & 20 & 3,73 \\
\hline & Facebook & 3,0 & 5,0 & 28,0 & 44,0 & 20,0 & \\
\hline \multirow{2}{*}{2} & \multirow{2}{*}{ Facebook reach people globally } & 3 & 0 & 12 & 47 & 38 & 4,17 \\
\hline & & 3,0 & 0,0 & 12,0 & 47,0 & 38,0 & \\
\hline \multirow{2}{*}{3} & I get the easiness to find latest information via & 3 & 5 & 27 & 44 & 21 & 3,75 \\
\hline & Facebook & 3,0 & 5,0 & 27,0 & 44,0 & 21,0 & \\
\hline \multirow{2}{*}{4} & My time become effective in searching information & 3 & 20 & 33 & 32 & 12 & 3,30 \\
\hline & via Facebook & 3,0 & 20,0 & 33,0 & 32,0 & 12,0 & \\
\hline \multirow{2}{*}{5} & I obtain information through Facebook with an & 2 & 12 & 31 & 32 & 23 & 3,62 \\
\hline & affordable cost & 2,0 & 12,0 & 31,0 & 32,0 & 23,0 & \\
\hline \multirow[t]{2}{*}{6} & I obtain information very quickly and precisely via & 1 & 19 & 30 & 36 & 14 & 3,43 \\
\hline & Facebook & 1,0 & 19,0 & 30,0 & 36,0 & 14,0 & \\
\hline \multirow{2}{*}{7} & Facebook is easy to use without requiring any & 1 & 5 & 15 & 50 & 29 & 4,01 \\
\hline & specific skills and knowledge & 1,0 & 5,0 & 15,0 & 50,0 & 29,0 & \\
\hline \multirow{2}{*}{8} & I can interact and provide a fast response among & 2 & 6 & 28 & 39 & 25 & 3,79 \\
\hline & Facebook users & 2,0 & 6,0 & 28,0 & 39,0 & 25,0 & \\
\hline \multirow{2}{*}{9} & \multirow{2}{*}{ I can replace my posting on Facebook quickly } & 1 & 5 & 21 & 45 & 28 & 3,94 \\
\hline & & 1,0 & 5,0 & 21,0 & 45,0 & 28,0 & \\
\hline \multirow{2}{*}{10} & \multirow{2}{*}{ I always get uptodateinformation on Facebook } & 3 & 11 & 22 & 45 & 19 & 3,66 \\
\hline & & 3,0 & 11,0 & 22,0 & 45,0 & 19,0 & \\
\hline
\end{tabular}

and 9 accessed less than once a month.

Further, the descriptive analysis of this research has shown that respondents'assessment onvariable $\mathrm{x}$ (Facebook usage) have generally been good. It can be shown from their responses which mostly showagreement on the indicators and the value of mean was above three. In the table 4, it shows that the range of respondents' answer on each statement of Facebook Usage was between 3.30 - 4.17.

Meanwhile, the descriptive analysis on variable y (reading interest) at news portal merdeka.com has been good enough, which can be shown from their responses which mostly showed neutral on the indicators and the value of mean in this dimension was 3 and above 3 . In the table 10 , it showed that the range of respondents' answer on each statement of reading interest was between $3.00-3.66$.

The first step to analyze the data was by examining the normality test. This study used SPSS 20 program to help the calculation of normality test on variable $\mathrm{x}$ and variable $y$, and the result showed that the Asymp Sig of variable $x$ and $y$ were 0.253 and 0.251 which were $>0.05$. Therefore, it can be concluded that the data from both variables were distributed normally.

As the result showed the data was normally distributed, then the next step for the research was to examine the value of influence thatconstruct by Facebook usage towards reading interest through Coefficient of determination $\left(\mathrm{R}^{2}\right)$ test. Based on the output of model summary, it was found that the value of $\mathrm{R}$ is 0.306 which means that the variable of Facebook usage influenced 
Table 5. Questionnaire Score on Reading Interest

\begin{tabular}{|c|c|c|c|c|c|c|c|}
\hline No & Statement & SDA & SD & $\mathrm{N}$ & A & SA & Mean \\
\hline \multirow{2}{*}{1} & \multirow{2}{*}{$\begin{array}{l}\text { I am interested in news caption published by merdeka.com on } \\
\text { Facebook }\end{array}$} & 3 & 17 & 34 & 29 & 17 & 3,40 \\
\hline & & 3,0 & 17,0 & 34,0 & 29,0 & 17,0 & \\
\hline \multirow{2}{*}{2} & \multirow{2}{*}{ I am interested in pictures published by merdeka.com on Facebook } & 3 & 16 & 33 & 37 & 11 & 3,37 \\
\hline & & 3,0 & 16,0 & 33,0 & 37,0 & 11,0 & \\
\hline \multirow{2}{*}{3} & \multirow{2}{*}{$\begin{array}{l}\text { Information published by merdeka.com on Facebook is always } \\
\text { interesting }\end{array}$} & 3 & 18 & 36 & 29 & 14 & 3,33 \\
\hline & & 3,0 & 18,0 & 36,0 & 29,0 & 14,0 & \\
\hline \multirow[t]{2}{*}{4} & \multirow{2}{*}{$\begin{array}{l}\text { I always get information in accordance with what I am looking for } \\
\text { through merdeka.com } \\
\text { posting on Facebook }\end{array}$} & 3 & 16 & 36 & 28 & 17 & 3,40 \\
\hline & & 3,0 & 16,0 & 36,0 & 28,0 & 17,0 & \\
\hline \multirow{2}{*}{5} & \multirow{2}{*}{$\begin{array}{l}\text { I want to visit news portal merdeka.com after obtaining information } \\
\text { from Facebook }\end{array}$} & 5 & 14 & 37 & 28 & 16 & 3,36 \\
\hline & & 5,0 & 14,0 & 37,0 & 28,0 & 16,0 & \\
\hline \multirow[t]{2}{*}{6} & $\begin{array}{l}\text { I am interested to read the rubrics in merdeka.com after obtaining } \\
\text { information via }\end{array}$ & 3 & 14 & 34 & 30 & 19 & 3,48 \\
\hline & Facebook & 3,0 & 14,0 & 34,0 & 30,0 & 19,0 & \\
\hline \multirow{2}{*}{7} & \multirow{2}{*}{$\begin{array}{l}\text { I open the link published by merdeka.com on Facebook and read } \\
\text { the article }\end{array}$} & 3 & 13 & 21 & 41 & 22 & 3,66 \\
\hline & & 3,0 & 13,0 & 21,0 & 41,0 & 22,0 & \\
\hline \multirow[b]{2}{*}{8} & \multirow{2}{*}{$\begin{array}{l}\text { I share the link of articles created by merdeka.com to my Facebook } \\
\text { page }\end{array}$} & 17 & 24 & 23 & 14 & 22 & 3,00 \\
\hline & & 17,0 & 24,0 & 23,0 & 14,0 & 22,0 & \\
\hline
\end{tabular}

$30.6 \%$ on reading interest at news portal merdeka.com whereas the rest $69.4 \%$ is influenced by other factors that did not analyzed in this research.

Regression test is used to predict the value of dependent variable caused by independent variable. The constant value resulted in 5.489 means that the value of reading interest when Facebook usage $=0$ is 5.489. It shows that the value was positive which means that every increment of a score from Facebook usage variable $(\mathrm{X})$ then the score of reading interest will increase 0.575 .

\section{Result and Discussion}

In order to answer the first research question about the usage of Facebook as publication medium, the result has shown that Facebook is already perceived as a good publication medium in terms of reach, accessibility, usability, immediacy, and permanence. The highest average score lied on the second statement of Reach indicator:
"Facebook reach people globally", which showed that Facebook was perceived as a social media that capable to connect with people globally, exchange information, as well as sustain relationship with people in different region or country all around the world. It is already in accordance to the basic of new media in which the new media provides an open, flexible information environment that allow individuals around the world to have mutual sharing, feedback and creative participants (Hearn et al, 2009). However, the lowest average score lied on the fourth statement in Accessibility indicator: "My time become effective in searching information via Facebook".

This research critically argues that Facebook as publication medium was still less effective in term of searching information. It might possible due to Facebook has been used for many purposes, such as sharing personal space, as a 
Table 6. Output of Model Summary

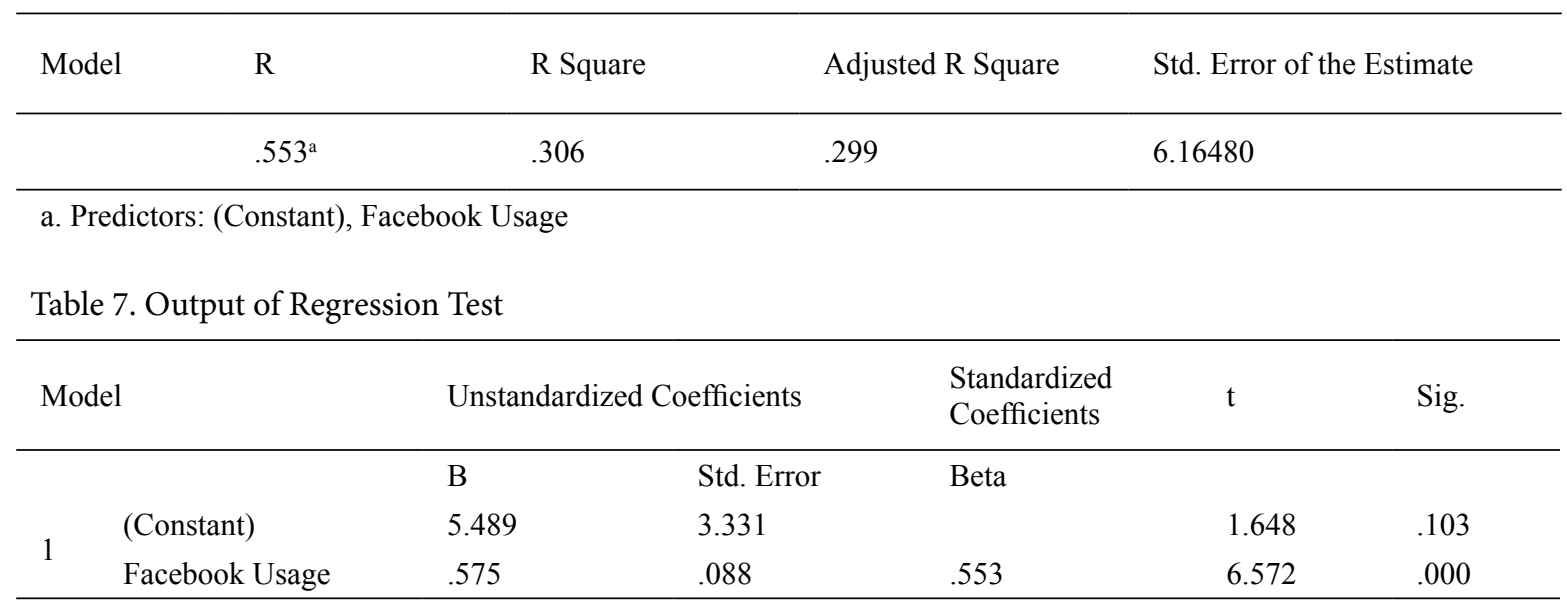

Table 8. Output of Normality Test(One-Sample Kolmogorov-Smirnov Test)

\begin{tabular}{llll}
\hline & & Facebook Usage & Reading Interest \\
$\mathrm{N}$ & & 100 & 100 \\
\hline \multirow{2}{*}{ Normal Parameters ${ }^{\mathrm{a}, \mathrm{b}}$} & Mean & 37.4000 & 27.0000 \\
& Std. Deviation & 7.07963 & 7.36220 \\
Most Extreme Differences & Absolute & .102 & .102 \\
& Positive & .062 & .087 \\
Kolmogorov-Smirnov Z & Negative & -.102 & -.102 \\
Asymp. Sig. (2-tailed) & & 1.016 & 1.018 \\
\hline
\end{tabular}

marketing tool, as well as for distributing and consuming news (Oeldorf, A., \& Sundar, S., 2015). Moreover, according to the study by Ju \& Chyi (2014), Facebook has several features for users to choose on, such as for playing games, viewing or uploading photos and videos. Thus, those various features and too much information on Facebook might lead to time ineffectiveness in searching information. In short, Facebook as a social media for publication medium has been successful in reaching people globally, but the weakness was on its use for time efficiency in searching information.

To answer the second research question on how the respondent's reading interest at news portal merdeka.com, the result has shown that all statements have average score 3 and above 3 . It means that news portal merdeka.com has applied well the AIDA marketing model of communication in increasing respondent's reading interest. It can be shown from the highest statement from the questionnaire that lied on the seventh statement of Action indicator: "I open the link published by merdeka. com on Facebook and read the article." It means that merdeka.com publications have been successful in gaining the attention of audiences, able to make audiences interested in finding out more, has arouse the desire or strong motivation to do the action, which lead to the action of open the link published and read the article. However, the lowest average score lied on the last statement of Action indicator:" I share the link of articles 
created by merdeka.com to my Facebook page." It showed that although respondents have shown their reading interest at news portal merdeka.com, but they tend not to share the articles to their Facebook page. This result critically argues that most respondents did not help merdeka.com spreading the news on their Facebook page which might lead to decrement of page's exposure of merdeka.com. According to Hermida (2009) and Baresch et al. (2011), when a user shares the news to his/her Facebook page, it gives article's exposure to at least 300 people because on average every Facebook user has at least more than 300 Facebook friends.

Moreover, based on the coefficient determination result showed that Facebook influenced $30.6 \%$ on reading interest at news portal merdeka.com. From the regression test, it can be seen that Facebook has significant influence towards reading interest at news portal merdeka.com, with every increment of a score from Facebook usage will increase 0.575 on reading interest. This result explained further the reasons why news media organizations all around the world have been using Facebook as Facebook influences reading interest to news portal. It supported the previous researches which explained that Facebook is being used as one of the strategy to reach as many audiences and to drive traffic to visit news portal (Hille et al., 2013; Singer et al., 2011).

Related to the theory Uses and Gratification, audiences have the role in choosing and using particular kind of media to fulfill or satisfy one or more of their needs. In this context, Facebook is being used as a publication medium by news portal merdeka.com to provide news, information and knowledge to audiences with the aim to fulfill audiences' cognitive need, and from the result, it showed that publication on Facebook increases the reading interest. Thus, it can be concluded that merdeka. com publications on Facebook were already in accordance or relevance to audiences' cognitive need as if the publications on Facebook were not relevance with the need of audiences, it will not increase their reading interest.

\section{Conclusion}

Based on the analysis of this research, researcher concluded the analysis as follows: 1) Facebook has beensuccessful in reaching people globally, however this research critically argued that Facebook was still less effective in searching information. 2) merdeka.com has been successfully applying AIDA marketing model of communication in increasing reading interest at its news portal. However, this research critically showed that respondents did not share the article to their Facebook page which might lead to decrement of page's exposure. 3) Publication by merdeka.com on Facebook are already in accordance or relevance to audiences' cognitive need which proved by the increment of audiences' reading interest.

This research is suggested for future researchers to analyze respondents' motives behind the reasons why they share article to Facebook page and re-analyze the same 
research but in different region as well as take a bigger sample size in order to provide more diverse and complete results. For practical recommendation, this research is suggested for news portal especially merdeka.com to maintain the use of Facebook as publication medium for delivering useful and up-todate news to societies but still following the term of journalism.

\section{References}

A. Pereira Correia, P., García Medina, I., Fabiola González Romo, Z., \& S. ContrerasEspinosa, R. (2014). The importance of Facebook as an online social networking tool for companies. International Journal of Accounting \& Information Management, 22(4), 295-320.

Alexa.(2016).facebook.com Traffic Statistics. Retrieved November 2016, from http:// www.alexa.com/siteinfo/facebook.com

Alexa.(2016). merdeka.com Traffic Statistics. Retrieved November 2016, from http:// www.alexa.com/siteinfo/merdeka.com

Alexa. (2016). The top 500 sites on the web. Retrieved November 2016, from http:// www.alexa.com/topsites

Baresch, B., Knight, L., Harp, D., \&Yaschur, C. (2011, April).Friends who choose your news: An analysis of content links on Facebook. In ISOJ: The Official Research Journal of International Symposium on Online Journalism, Austin, TX (Vol. 1, No. 2, pp. 1-24).

Boone, L. E., \& Kurtz, D. L. (2013). Contemporary marketing. Cengage learning.

Boyd, M. D., \& Ellison, B. N. (2008).Social Network Sites: Definition, History and Scholarship. Journal of ComputerMediated Communication.13, 210 - 230. doi:10.1111/j.1083-6101.2007.00393.x
Bryman, A., \& Cramer, D. (2005).Quantitative data analysis with SPSS 12 and 13: a guide for social scientists. Psychology Press.

Cox, J. B. (2016). News orgs post more often on Twitter than on Facebook. Newspaper Research Journal, 0739532916662485.

Creswell, J. W. (2013). Research design: Qualitative, quantitative, and mixed methods approaches. Sage publications.

Croucher, S. M., \&Cronn-Mills, D. (2014). Understanding communication research methods: a theoretical and practical approach. Routledge.

Currie, T. S. (2006).Online News.Submitted to the Faculty of Extension (Doctoral dissertation, University of Alberta).

Dean, A. (2014). Definition Facebook. Retrieved November 2016, from http:// whatis.techtarget.com/definition/ Facebook

Dijk, P. J. (2005). The Network Society: Social Aspects of New Media.

Eki.(2016). PrinsipDasarJurnalistik Online menurut Paul Bradshaw. Retrieved December 2016, from https://www. ekibaehaki.com/prinsip-dasarjurnalistik-online-menurut-paulbradshaw/

Facebook newsroom.(2016). Stats. Retrieved November 2016, from http://newsroom. fb.com/company-info/

Franklin, B. (2008). Pulling newspapers apart: Analysing print journalism. London: Routledge.

Greer, J. D., \& Yan, Y. (2011).Newspapers connect with readers through multiple digital tools. Newspaper Research Journal, 32(4), 83.

Haristya, H., \&Suwana, I. (2012).The CredibilityofNewsPortalinIndonesia(An Exploratory Study). Communicare, 5(2), 189-197. 
Hassan, S., Nadzim, S. Z. A., \&Shiratuddin, N. (2015).Strategic use of social media for small business based on the aida model.Procedia-Social and Behavioral Sciences, 172, 262-269.

Hearn, G. N., Tacchi, J. A., Foth, M., \&Lennie, J. (2009).Action research and new media: Concepts, methods and cases. Hampton Press.

Hermida, A. (2009, September 15). FoJ09 talk: Twitter as a system of ambient journalism. [Web log post]. Retrieved from http://reportr.net/2009/09/15/foj09talk-twitter-as-a-system-of-ambientjournalism/

Hermida, A., Fletcher, F., Korell, D., \& Logan, D. (2012). Share, like, recommend: Decoding the social media news consumer. Journalism Studies, 13(5-6), 815-824.

Hille, S., \& Bakker, P. (2013).I like news. Searching for the 'Holy Grail'of social media: The use of Facebook by Dutch news media and their audiences. European Journal of Communication, 28(6), 663-680.

Hopkins, H. (2010, February 3). Facebook largest news reader?[Web log post]. Retrieved from http://weblogs.hitwise. com/us-heather-hopkins/2010/02/ facebook_largest_news_reader_1.html

Hosan, A. A. E. The Effect of Communication Performance of Media on User's Perception of Social Network.

Howe, J (2011). Social Media and News Consumption

Infinitdatum.(2015). 100 Social Media Facts and Statistics 2015. Retrieved November 2016, from http://www.infinitdatum. com/social-media-statistics/

Internet World Stats. (2016). Top 20 Countries With the Highest Number of Internet
Users. Retrieved November 2016, from http://www.internetworldstats.com/ top20.htm

Joinson, A. N. (2008, April). Looking at, looking up or keeping up with people?: motives and use of facebook. In Proceedings of the SIGCHI conference on Human Factors in Computing Systems (pp. 1027-1036).ACM.

Ju, A., Jeong, S. H., \&Chyi, H. I. (2014).Will social media save newspapers? Examining the effectiveness of Facebook and Twitter as news platforms. Journalism Practice, 8(1), 1-17.

Kaplan, A. M., \&Haenlein, M. (2010).Users of the world, unite! The challenges and opportunities of Social Media.Business horizons, 53(1), 59-68.

Kwok, L., \& Yu, B. (2015).Taxonomy of Facebook messages in business-toconsumer communications: What really works?.Tourism and Hospitality Research, 1467358415600214.

Lariscy, R.W., Tinkham, S.F. and Sweetser, K.D. (2011), "Kids these days: examining differencesin political Uses and Gratifications, internet political participation, political informationefficacy, and cynicism on the basis of age", American Behavioral Scientist, Vol. 55 No. 6,pp. 749-764.

Li, C., \&Bernoff, J. (2011). Groundswell: Winning in a world transformed by social technologies. Harvard Business Press.

Ludtke, M. (2009).Let's Talk: Journalism and Social Media.3(4).Retrieved November, 2016.

Mesole, F. F. (2014). Use of Social Media as an Alternative News Sources Among University Students (Doctoral dissertation, Eastern Mediterranean University (EMU)DoğuAkdenizÜniversitesi (DAÜ)).

Merdeka.com. Retrieved November, 2016 from https://www.merdeka.com/company/ tentang-kami.html 
Nightingale, W., 2012.Positivist Approach to Research [pdf] Available at: <http:// www.wider-mind.com/research/wdnpositivism-v2.pdf>

Oeldorf-Hirsch, A., \&Sundar, S. S. (2015). Posting, commenting, and tagging: Effects of sharing news stories on Facebook. Computers in Human Behavior, 44, 240-249.

Palser, B. (2011). Strategies for facebook: news outlets are devoting a great deal of energy to heightening their presence on social media. American Journalism Review, 33(2), 58-59.

Papacharissi, Z., \&Mendelson, A. (2011).12 Toward a new (er) sociability: uses, gratifications and social capital on Facebook (pp. 212-230). New York: Routledge.

Park, Namsu, Kerk F. Kee, and Sebastián Valenzuela."Being immersed in social networking environment: Facebook groups, Uses and Gratifications, and social outcomes. "CyberPsychology\& Behavior 12.6 (2009): 729-733.

Pew Research (2016).Facebook Usage. Retrieved November 2016, from h t t p :// s earch.proquest.com/ docview/1459193615? accountid $=38628$

Picard, R. G. (2009). Blogs, tweets, social media, and the news business. Nieman Reports, 63(3), 10.

Purcell, K., Rainie, L., Mitchel, A., Rosenstiel, T., \& Olmstead, K. (2010, March).Understanding the Participatory News Consumer: How Internet and Cell Phones users have Turned News into a Social Experience. Kristen, 1- 51. Retrieved November 2016, from http:// www.pewinternet.org/files/oldmedia/ Files/Reports/2010/PIP_Understanding the_Participatory_News_Consumer.pdf

Ricardo LimongiFrança Coelho Denise Santos de Oliveira Marcos InácioSevero de Almeida
, (2016),'Does social media matter for post typology. Impact of post content on Facebook and Instagram metrics. Online Information Review, 40(4), 458-471.

Santoso, S. (2014).StatistikMultivariat. Jakarta: PT Elex Media Komputindo.

Sekaran, U., \&Bougie, R. (2013). Research Methods for Business: A Skill Building Approach (6th Edition ed.).

Seward, Zachary M. 2008. "NYT Sees Success in Facebook Push." Nieman Journalism Lab.

Singer, Jane B., Hermida, Alfred, Domingo, David, Heinonen, Ari, Paulussen, Steve, Quandt, Thorsten, Reich, Zvi and Vujnovic, Marina (2011) Participatory Journalism: guarding open gates at online newspapers, New York: Wiley Blackwell.

Stassen, W. (2010).Your news in 140 characters: exploring the role of social media in Journalism. Global Media Journal, 4(1), 116- 131.Retriesved November 2016, from http://reference.sabinet.co.za/webx/ access/electronic_journals/glomed_africa/ glomed_africa_v4_n1_a7.pdf

Statista. (2016). Leading countries based on number of Facebook users as of May 2016 (in millions). Retrieved November 2016, from https:/www.statista.com/ statistics/268136/top-15-countries-basedon-number-of-facebook-users/

Statista.(2016). Most famous social network sites worldwide as of September 2016, ranked by number of active users (in millions). Retrieved November 2016, from https:// www.statista.com/statistics/272014/globalsocial-networks-ranked-by-number-ofusers/

TechTarget.(2015). Web 2.0.Retrieved November 2016, from http://whatis.techtarget.com/ definition/Web-20-or-Web-2

Veltman, K. H. (2006). Understanding new media: augmented knowledge \& culture. University of Calgary Press. 
Waldman, Steven. Information needs of communities: The changing media landscape in a broadband age. DIANE Publishing, 2011.

Wardani, A. S. (2016). 95 PersenPengguna Internet Indonesia Akses BeritaLewatPonsel. Retrieved November 2016, from http://tekno. liputan6.com/read/2568448/95-persenpengguna-internet-indonesia-aksesberita-lewat-ponsel

WeAreSocialSingapore (2016).The latest stats in web and mobile in Indonesia (INFOGRAPHIC). Retrieved November 2016, from http://wearesocial.sg/

West, Richard L., and Lynne H. Turner. Introducing communication theory: Analysis and application. McGraw-Hill Humanities/Social Sciences/Languages, 2010.
Whiting, A., \& Williams, D. (2013). Why people use social media: a Uses and Gratifications approach. Qualitative Market Research: An International Journal, 16(4), 362-369.

Winter, S., Brückner, C., \&Krämer, N. C. (2015). They came, they liked, they commented:Socialinfluenceon Facebook news channels. Cyberpsychology, Behavior, and Social Networking, 18(8), 431-436. www.niemanlab.org/2008/11/ nyt-claims-success-in-facebook-push/

Zikmund, W. G., Babin, B. J., Carr, J. C., \& Griffin, M. (2013). Business Research Method (9th Edition ed.). Singapore

Zuhra, W. U. (2016). Media Massa Tak LagiBisaBergantungPadaFacebook. Retrieved November 2016, from https:// tirto.id/media-massa-tak-lagi-bisabergantung-pada-facebook-bqjK 